\title{
Rebecca Nedostup
}

\section{BURYING, REPATRIATING, AND LEAVING THE DEAD IN WARTIME AND POSTWAR CHINA AND} TAIWAN, 1937-1955*

\begin{abstract}
The burial of war dead was a key element of displacement and community formation during wartime and postwar China and Taiwan, 1937-1955. Reckoning with the physical burial and spiritual pacification of civilian as well as military dead posed practical and epistemological problems for the tens of millions forced to migrate amid shifting political and military boundaries. Various populations of living and dead refugees became increasingly politicized on the national and international levels, affecting local rituals and family burials. The accumulation of unidentified or lost bodies raised the stakes for the incorporation of the known dead into local, translocal, or national communities. The moral imperative of families and lineages to reconstitute themselves in the aftermath of war was made concrete via the extensive networks of locally-identified charitable organizations who worked to transport coffins back "home" from China's interior. The Nationalist government, meanwhile, prioritized symbolic control over military heroes in ways that ignored or eschewed burial and family ritual. The KMT and those who fled with them to Taiwan in 1949 were then cut off from their national as well as family graves, and struggled to find ritual and practical methods of overcoming or temporarily ameliorating political boundaries, geographic distance, and the passage of time.
\end{abstract}

\section{Keywords}

war, displacement, refugees, death, burial, Taiwan, Dachen, Wuxi, Chongqing

Many years later, when she was fed up with being accused, along with the political regime that came from the China mainland, of "not really considering this place as a permanent home", she

Brown University, email: rebecca_nedostup@brown.edu

* My gratitude to Janet Y. Chen, Kevin Kenny, Rana Mitter, Nicholas Stargardt, and the participants of the Columbia Modern Chinese History Seminar, the Oxford Workshop on Relief and Reconstruction in Wartime and Postwar China, 1937-1949, the Approaching War Seminar at Brown University's Pembroke Center, the Davis Seminar at Princeton University, and the members of the Genealogy and Local History Section of the International Federation of Library Associations, all of whom commented on earlier versions of this work, as did faculty and students in the history departments at Columbia, National Tsing Hua (Taiwan), and Peking Universities and the Center for Chinese Studies, National Central Library, Taiwan. Portions of this research were conducted under a fellowship from Center for Chinese Studies, National Central Library, Taiwan. I also owe a debt to Roger Shih-chieh Lo and Chiang Chia-ping for enabling fieldwork, and to the journal's reviewers and editors for helping me to clarify my argument. 
really did ruminate over the reasons they never really did come to consider this piece of land as a place in which to take root in their lifetime - at least not during those years - She came to a very simple conclusion, that is, they didn't have any tombstones to sweep during Tomb-Sweeping Festival.

—Chu T'ien-hsin 朱天心, “In Remembrance of My Buddies from the Military Compound” 《想我眷村的兄弟們》, translated by Michelle Wu. ${ }^{1}$

Home is where the tombs are.

At least, this is the argument that Chu T'ien-hsin made in her 1992 memoiristic short story, "In Remembrance of My Buddies from the Military Compound." Her narrator had grown up in one of the mainly urban small neighborhoods (hardly rising to the status or size of "bases") given to those military followers of Chiang Kai-shek's Nationalist government on Taiwan who had been so lucky as to bring family members with them from the mainland. The juancun 眷村 (military compounds or, technically, military dependent compounds) were sites of simultaneous displacement and institutionalization, loss and privilege. Residents of the juancun belonged to branches of the armed forces that were most highly valued by the state. Yet the level of value determined the amount of space they shared with their wives, children, and occasionally parents and other relatives, and housing clearly demarcated both branch and rank status. Corresponding "new villages" (xincun 新村) housed select civil servants, many of them veterans, who were similarly prized by the KMT state. Thus, the residents' very presence in the compounds spoke of privilege compared both to several strata of Taiwanese society and to their lower-ranking mainlander comrades. Yet all of these groups had displacement and loss in common. In the case of the juancun residents, like "mainlanders" in general, the territorial division between the Republic of China on Taiwan and the People's Republic of China on the mainland separated them in time and space from their hometowns and various adopted homes. Such parting of course extended to people as well: a partitioning between groups of friends, relatives and-as Chu T'ien-hsin writes in the passage above-among the dead and "their" living.

This last separation is what Chu's narrator slowly comes to pinpoint as the source of the juancun residents' awkwardness and loss of place, both figurative and literal. When her narrator complains of "being accused... of not really considering this place a permanent home," Chu refers to the great political awakening that arose with Taiwan's democratization. Taiwanese who had resided on the island at the time of retrocession from Japanese colonization in 1945 began to speak of their displacement by the coming of the Nationalists. Her narrator counters later in the story that at least Taiwanese children could see where their ancestors were buried. In fact the ability of all on the island to fully know the fate of their dead during the period of martial law could be considerably murkier that such comments implied. More broadly, however, Chu's is a kind of cultural-political argumentation that relies on a Chinese cultural cliché-that the family burial site determines home place. It suggests that another layer of displacement might lie beneath the globally familiar images of refugee masses on the move-on foot,

\footnotetext{
${ }^{1}$ In The Last of the Whampoa Breed: Stories of the Chinese Diaspora, edited by Pang-yuan Chi and David Der-wei Wang (New York: Columbia University Press, 2003), 247-48.
} 
on carts, on trains, on ships_-and in need of succor and aid. The displaced, it emerges, encompassed the unseen as well as the seen.

When one digs deeper into the social reality behind the trope of "home" as centered around the family graves, it emerges that-like ancestor veneration in general-it exists as a reciprocal relationship. That is, as the anthropologist Rubie Watson writes, "the link between an ancestor in his grave and his descendants is a strong and consequential one," in which the proper placement of the burial site affects the prospects of future generations. But, she points out, this works only if the grave is kept up, which often requires the establishment of networks and estates for that purpose (particularly in southeastern China. $)^{2}$

Thus, Watson remarks, "some ancestors are cherished and some abandoned" —and not even during circumstances of war and displacement. These are categories of the dead who are, at least initially, recognized, claimed, counted, and known. What of those who died amid much greater confusion and loss? The numbers of Chinese civilian and military dead for the Second Sino-Japanese War alone are hardly confirmed, circling 20 million but constantly revisited. ${ }^{3}$ The total count of those lost to the conflicts of the civil war and the "hot" Cold War that followed is even more obscure. In fact it is the very uncertainty of those numbers that should prompt us to ask different sorts of questions about the experience of wartime death and displacement.

Among those dead, some were cherished while others were abandoned; some were counted while others remained indistinct; and some were kept close while others were lost. The proportions were not equal. The elaborate individual repatriation and burial processes afforded Minsheng Shipping Company director Gan Nanxing and $33^{\text {rd }}$ Army Group Commander Zhang Zhizhong -whose bodies were permitted to be transported through military zones from north China to Chongqing in 1937 and 1940, respectively -were exceptional, for they were people of exceptional status. ${ }^{4}$ More common were rapid battlefield burials by "hygiene corps" (weisheng dui 衛生隊), mass urban graves for the victims of bombing and disease, and unidentified corpses that were dealt with by shantang 善堂 and other charitable groups. Through the work of historians such as Christian Henriot, a picture is emerging of the systems by which particular cities such as Shanghai coped with the crises. ${ }^{5}$ Such mechanisms frequently prioritized hygiene and public order over identification and notification. Indeed, it is when placed against the background of such vast uncertainty that the weight assigned to the known dead during this period begins to make sense.

\footnotetext{
${ }^{2}$ Rubie S. Watson, "Remembering the Dead: Graves and Politics in Southeastern China," in Death Ritual in Late Imperial and Modern China, edited by James L. Watson and Evelyn S. Rawski (Berkeley: University of California Press, 1988), 203-27, 207.

${ }^{3}$ In his definitive account of the war, for instance, Rana Mitter notes that 14 million is the conservative estimate, but that "the toll that the war inflicted on China is still being calculated." Forgotten Ally: China's World War II, 1937-1945 (New York: Houghton Mifflin, 2013), 5.

${ }^{4}$ On the former, Chongqing Municipal Archives (hereafter CMA) 0081:3:657, 104-105_1; on the latter, Arthur Waldron, "China's New Remembering of World War II: The Case of Zhang Zizhong," Modern Asian Studies 30:4, Special Issue: War in Modern China (Oct., 1996), 945-78.

${ }^{5}$ Christian Henriot, "Invisible Deaths, Silent Deaths: "Bodies without Masters' in Republican Shanghai," Journal of Social History 43:2 (2009), 407-37, and Scythe and the City: A Social History of Death in Shanghai (Stanford: Stanford University Press, 2016).
} 
Thus, just as displaced persons can of necessity build communities among strangers from other families and regions while maintaining ties with their home places, they press forward with revised lives while dealing with the physical or felt presence of the dead. The proper, hasty, or absent burial of the dead affects the establishment of both physical community and senses of "home" and family as much as the housing and settlement of living displaced persons. The extent to which customary patterns of each were disrupted by war and responses to it is the subject of my inquiry in this article, with a particular focus on how the broad frameworks of politicization and militarization of displaced persons affected the options for burying and honoring the civilian war dead, in addition to the military heroes whose stories dominate state narratives and therefore the bulk of historical documentation, including personal accounts as well as archives. I draw material from a forthcoming monograph that explores the experience of wartime displacement, spatially, chronologically, and ritually, through a series of distinct but linked place-based histories (of Jiangsu, Chongqing and Sichuan, and Taiwan). I focus primarily on Nationalist- or Japanese-controlled areas in part to seek source bases that pose some potential of yielding narratives that augment, if not entirely evade, those provided by party, state, and military materials. I also hope to increase our understanding of the experience of displacement in China and Taiwan by adding cases to the small but vital and growing field of refugee studies that draw on sites, such as Henan, Hong Kong, and Shanghai, that received attention from the international refugee regime. ${ }^{6}$

Two case studies explore respectively the repatriation of civilian coffins from the Chinese wartime capital of Chongqing to eastern China in the immediate aftermath of the Japan war, and the politically charged honoring of abandoned military dead alongside abandoned civilian homes and family graves in 1955 Taiwan. Although the conditions of war and increased national control threatened past mourning practices, by the same token those non-state actors with the means to control burial and mourning assigned it all the greater moral significance amid the uncertainties and chaos of violence and displacement. The ability or inability to mourn properly took on the symbolic weight of the entire experience of war and dislocation. ${ }^{7}$

\footnotetext{
${ }^{6}$ Leading the way on Henan is Micah Muscolino's environmental study, The Ecology of War in China (Cambridge: Cambridge University Press, 2014); Kathryn Edgerton-Tarpley's research focuses more specifically on refugee aid, e.g. "Saving the Nation, Starving the People? The Henan Famine of 1942-1943," in 1943: China at the Crossroads, edited by Joseph W. Esherick and Matthew Combs (Ithaca: Cornell University Press, 2015), 323-64. On Hong Kong and the overall context of China in the postwar international refugee regime, see Glen Peterson, "Sovereignty, International Law, and the Uneven Development of the International Refugee Regime," Modern Asian Studies 49 (2015), 439-68, 445-57, doi:10.1017/S0026749X14000341; and Rana Mitter, "Imperialism, Transnationalism, and the Reconstruction of Post-war China: UNRRA in China, 1944-7," Past and Present 218 (suppl. 8) (2013), 51-69, doi:10.1093/pastj/gts034. On the IRO and UNRRA's activity regarding people of Chinese descent outside of China, see Meredith Oyen, "The Right of Return: Chinese Displaced Persons and the International Refugee Organization, 1947-56," Modern Asian Studies 49 (2015), 546-71. doi:10.1017/S0026749X14000420.

${ }^{7}$ Examples of recent work dealing with the subject of refugees include Diana Lary, The Chinese People at War: Human Suffering and Social Transformation, 1937-1945 (New York: Cambridge University Press, 2010); Lu Liu, "A Whole Nation Walking: The 'Great Retreat' in the War of Resistance, 1937-1945" (PhD diss., University of California, San Diego, 2002); Stephen R. MacKinnon, Wuhan, 1938: War, Refugees, and the Making of Modern China (Berkeley: University of California Press, 2008); Rana Mitter, "Classifying Citizens in Nationalist China during World War II, 1937-1941," Modern Asian Studies 45:2 (2011), 243-75; as
} 
To highlight the multiple and linked displacements of civilians, draftees, and career military, I am considering as a "long war" the period beginning with the war with Japan in 1937, through Taiwan's retrocession, the rise of civil war in the mainland and Nationalist flight to Taiwan, and early Cold War period (through the end of the Second Strait Crisis in 1959). Of course this notional "long war" connects various conflicts of differing nature, but from the point of view of the displaced certain experiences recur throughout. In particular, new patterns of long-distance displacement and mechanisms of total and political warfare arise to intermix with older, still extant patterns of short-term, short-distance flight. Such personal, familial, and local movements take place against a background in which the "refugee" is increasingly mediated as a political and cultural trope. Importantly, this often occurred without reference to the emerging, "international" refugee regime based in Europe. In the near term, this was in part because this regime did not classify most of the persons displaced by China and Taiwan's long war as refugees, focusing as it did on the critical distinction of crossing international borders. In the long term, as Glen Peterson has shown, the antecedents of this regime had been disinclined to consider the legal ramifications of displaced Asians and Chinese in any case. ${ }^{8}$ Such choices would have lasting historiographic consequences as well as immediate practical ones: despite indications that as much as 20 to 25 percent of the Chinese population was displaced by the Second Sino-Japanese War, for example, the absence of ethnic Chinese refugees outside of colonial settings from the records of the International Refugee Organization and the United Nations Relief and Rehabilitation Administration has meant that ethnic Chinese refugees are consequently minimized in world history. ${ }^{9}$ It is as a reflection of this historical circumstance that in this study, "displacement" and "displaced persons" are preferred as a general description of a social condition, and are not intended to indicate present day legal usages of "internally displaced persons." By the same token, "refugee" generally appears here when historical actors deployed a term such as nanmin 難民一which at this time, much to the irritation of UNRRA workers, was liberally used in Chinese to designate any person in flight.

The new distances, boundaries, citizenship regimes, and eventually borders that developed increasingly challenged the ability of private citizens to maintain control over the bodies and burial of their lost family members and associates. At the same time, political authorities including the Nationalist and Wang Jingwei governments - and later, the

well as R. Keith Schoppa, In A Sea Of Bitterness: Refugees During the Sino-Japanese War (Cambridge, Mass.: Harvard University Press, 2011.)

${ }^{8}$ Peterson, "Sovereignty, International Law."

${ }^{9}$ For example, it is primarily the Hong Kong and Tibet cases that are addressed in Peter Gatrell's influential The Making of the Modern Refugee (Oxford: Oxford University Press, 2013). On background and influence of the IRR, see Glen Peterson, "To Be or Not to Be a Refugee: The International Politics of the Hong Kong Refugee Crisis, 1949-55," Journal Of Imperial \& Commonwealth History 36:2 (June 2008), 171-95, and Peterson, "Sovereignty, International Law"; Laura Makodoro, "Surveying Hong Kong in the 1950s: Western Humanitarians and the 'Problem' of Chinese Refugees," Modern Asian Studies 49 (2015), 493-524, doi:10.1017/ S0026749X14000365; Pamela Ballinger, "Entangled Histories or 'Extruded' Histories? Displacement, Refugees, and Repatriation after World War II," Journal of Refugee Studies 25:3 (2012), 366-86; Madeleine Hsu, The Good Immigrants: How the Yellow Peril Became the Model Minority (Princeton: Princeton University Press, 2015). 
Chinese Communist Party-recognized the importance of asserting such control, whether in the form of enabling burial of war victims in general or ennobling the stature of dedicated war heroes in particular. ${ }^{10}$ Mourning and burial, however, refused to be stabilized.

For a substantial group of people, the resolution of wartime displacement was understood not so much in terms such as "victory" (shengli 勝利) but reconstruction and return (jianshe 建設, huanxiang 還鄉), or in vocabularies whose political valence intermingled with broader cosmological meanings. Editing the 1948 edition of the Ding lineage's genealogy in Danyang county, Jiangsu (the $13^{\text {th }}$ edition and the first since an equally significant post-Taiping Rebellion revision), $37^{\text {th }}$ generation descendant Shao Zengsheng linked physical drifting to a loss of lineage order and morality. After the area fell to the Japanese, he wrote, there were no keepers of the genealogy left in the town, and those in the country had no means of withdrawal: "fear and hate in people's minds spurred a chaotic retreat to the interior [daluan houliu 大亂後流] and the links to family and ritual were almost severed for good." In the hundreds of genealogies that emerged in the postwar years, "drifting" (liu 流) is a term that appears repeatedly as a way of describing civilian wartime experience. ${ }^{11}$ Thus the war had unleashed not only terror and dislocation, but a kind of dislocation that was in its nature destructive of the basis of Chinese society (as opposed to more familiar patterns of migration and sojourning). ${ }^{12}$ The very act of compiling a new edition of the genealogy, then-an effort which required gathering lineage members and often concurrently reclaiming and/or refurbishing the lineage hall and other collective property—constituted a restorative act in itself. Issuing of the new edition, when completed, might entail a further series of rituals: the physical gathering of lineage members, feasting (surely visible and welcome during a time of continued scarcity), and rites of propitiation and blessing.

The Ding volume was but one among a wave of new genealogies published in formerly occupied Jiangsu in the late 1940s. These acts accompanied a spate of reestablishment or new founding of charities and socio-religious organizations, including redemptive societies. This in turn followed on the "return" of bodies from the interior by native-place associations, and their interment in communities throughout Jiangsu and neighboring provinces. The term shanhou 善後 is most familiar in modern Chinese historical scholarship as a term of politicized war and disaster negotiation, relief and rehabilitation (the 1925 Shanhou huiyi 善後會議, for example—essentially peace talks—or the Chinese National Relief and Rehabilitation Administration [Shanhou jiuji zongshu 善後救濟總 署], a.k.a. CNRRA, the main state node for relief management starting from the Second Sino-Japanese War). Yet in the long recuperation from the Taiping Rebellion-a

\footnotetext{
${ }^{10}$ The most obvious rivalry of symbolism and legitimacy was between the Nationalist Party (Kuomintang, or KMT) led government, with its wartime capital in Chongqing, and the rival "national government" established in 1940 Nanjing by Wang Jingwei with the support of the Japanese. The larger battle for wartime political legitimacy, however, also featured the Communist base areas, the most famous of which was at Yan'an, and Japan's regime of Manchukuo, among other contestants. The latter lie outside the geographic scope of this study.

${ }^{11}$ A preliminary survey of the holdings of the Shanghai Library genealogy collection, for instance, yields a little under 200 editions produced in Jiangsu province alone between 1945 and 1951, peaking in 1948. A similar pattern holds for the smaller collection of the National Library in Beijing.

${ }^{12}$ Danyang dongmen Ding shi zupu ershiliu juan 丹陽東門丁氏族譜二十六卷 (丹陽 1948), preface 1, 1 b.
} 
process that we should remember was in the lifetimes of some who encountered the twentieth-century wars - shanhou indicated postwar recovery in a much broader sense. It encompassed the philanthropy of the shantang 善堂, which would include the provision of coffins and burial space as well as food, clothing, and medicine for the living. It also indicated the realm of the post-rebellion Shanhou ju 善後局, state agencies set up by officials such as Zeng Guofan in order to pursue reconstruction in every conceivable sense: economic, administrative, commemorative, social, burial, and ritual. ${ }^{13}$

A few decades into the Republican era, state officials such as those in the Nationalist regime had rejected this broader sense of governmental responsibility, both from the rise of state secularism and from increasing constraints on the state's ability to take care of the dead produced by expanding mass violence and environmental disaster. This did not mean that citizens accepted this restricted conception of sovereignty and duty, however. Thus the conclusion of the Second Sino-Japanese War saw people embracing the full range of meaning of the term shanhou, including properly arranging the end of life.

\section{REFUGEES AND BORDERS}

The physical location of dead bodies and the ritual surrounding them mattered during the long twentieth-century Chinese war not simply out of natural course, but because the question of home attachment had become a critical element of war policy, spun to a high moral level by state and private actors alike, and dead bodies often lay at the bottom of it. For state-building entities in wartime such as the Nationalist government in Chongqing, the Sino-Japanese occupation regimes, and the Communist base area governments, the broadest notion of displacement stretched well beyond groups of scattered persons seeking refuge from the depredations of warfare. Each side sought to retain and move economic, governmental, cultural, and personnel resources for immediate tactical survival and long-term strategic victory. Viewed in this light, it is hardly surprising that these combatants similarly viewed urgently displaced persons as potential resources in political-military strategy. For example, both Nationalist government officials on various levels and privately-funded relief organizers advocated the resettlement of rural and sometimes even urban refugees in agricultural colonies on ostensibly fallow remote land. Such plans, which were executed around the country-from ethnicallydiverse "border regions" in the north and northwest to eastern locales such as Jiangxi and the southwest KMT base-claimed an economic foundation, but also created a buffer zone of war refugees in the previously politically and militarily unstable inland areas into which KMT forces were now moving. Seen in a longer historical framework, such programs link to disaster-relief plans of the late Qing and early Republic on one side and the KMT-CCP civil war and Nationalists' settlements on Taiwan after 1949 on another-and possibly to a larger comparison with the empire-building of the Qing and Japanese states. In this trajectory, refugees become agents and subjects of Chinese

\footnotetext{
${ }^{13}$ Tobie Meyer-Fong, What Remains: Coming to Terms with Civil War in 19th Century China (Stanford: Stanford University Press, 2013), 27-28; Chuck Wooldridge, City of Virtues: Nanjing in an Age of Utopian Vision (Seattle: University of Washington Press, 2015), 119-22.
} 
border-creation and state-building. In order to carry this out, planners recognized that they also had to embark on a larger project of inducing citizens to be more receptive to moving their homes in the service of the nation. ${ }^{14}$

Theorists and practitioners of the drive to kenzhi (墾殖, "cultivate"-or more broadly translated for this context, "settle") argued that this was one area in which refugees particularly needed guidance. Tang Qiyu and Zhou Yongshu, two authors of handbooks on the settlement movement in Jiangxi province, summed up the ideological as well as pragmatic role of rural settlements. Zhou remarked that actual farmers living on the front were best selected for such projects, because they will have "really felt the coercion of death and war." Thus they would make receptive targets for propaganda. In Zhou's view the lessons should include not only the usual content of wartime mobilization and patriotism, but firm imprecations to abandon house and property-not simply until danger passed, but for the foreseeable future. Zhou discussed how the organizers of settlements could provide practical incentives in order "to give farmers the courage to leave their land," while Tang suggested a combination of rhetorical and punitive devices to keep settlers at their new destination. It was perhaps not enough for planners to urge farmers to resist nostalgia and speak of the settlements as their "second home place." They had to warn the settlers that any choice to return to their war-wracked homes would result in fines and obligations to refund the government's cost outlays. ${ }^{15}$ Planners such as Zhou and Tang thus wrote off any lingering attachment to home as based in irrational emotions such as nostalgia (which were not as useful for their purposes as the emotions of fear and hate). This absolved them from inquiring into any material or social sources of rural refugees' connections to home. Instead, the refugee, once mobile, was seen as perpetually mobile and mobilizable.

Two interlinked threads in this narrative hold significance for the general history of the wartime displaced during this period: the increasing politicization of the figure of the

\footnotetext{
${ }^{14}$ At the national level, this was visible in the "Plan for Executing Refugee Settlements" (Nanmin kenzhi shishi dagang 難民墾殖實施大綱) (1938-41) (File of March-June, 1938, National Government Office of the President archives 270-0925, pp. 1039-65; Judicial Yuan ruling 216, March 3, 1941, Judicial Ministry for the Executive archives 154; Academia Historica, Taiwan. On October 4, 1938, the Military Affairs High Commission revised and replaced the original prewar measure.) For descriptions of plans in various regions of China, see Nanchuan Jinfoshan kenzhi weiyuan hui choubei hui 南川金佛山墾殖委員會籌備會， Nanchuan Jinfoshan kenzhi jihua shu 南川金佛山墾殖計畫書 (Nanchuan? 1938); Sichuan dongnan bianqu Xi Xiu Qian Peng Shi wuxian kenzhi diaocha baogao shu 四川東南邊區西秀黔彭石五縣墾殖調查報告書 (Chongqing?, 1938?); Liu, "A Whole Nation Walking," 272-73, 276-77; Micah S. Muscolino, "Refugees, Land Reclamation, and Militarized Landscapes in Wartime China: Huanglongshan, Shaanxi, 1937-45," Journal of Asian Studies 69 (2010), 453-78; Andres Rodriguez, "Building the Nation, Serving the Frontier: Mobilizing and Reconstruction China's Borderlands during the War of Resistance (1937-1945)," Modern Asian Studies 45 (2011), 345-76.

Land reclamation plans were executed in late 1940s Jiangsu both to receive returnees from the interior and bear those escaping civil battle in the north of the province (Archives of the Jiangsu Provincial Government Department of Social Services, June 1946-August 1947, Jiangsu Provincial Archives 1009 jia 200, 15131639.)

${ }^{15}$ Zhou Yongshu 周永澍, Wo suo jiandao de nanmin yiken wenti 我所見到的難民移墾問題 (Nanchang, 1938), 25-28. Tang Qiyu 唐啓宇, Nanmin yu kenzhi 難民於墾殖 (Nanchang?, 1938), 4. The CCP produced its own version of political arguments promoting the idea that refugees could contribute to productivity and not wallow in sorrow or nostalgia for homes left behind. One example is the Yan'an era pamphlet Nanmin laodong yingxiong Chen Chang'an 難民勞動英雄陳長安 (Yan'an, 1944).
} 
refugee, and the privileges as well as tensions a name could provide. This generated around how people could transport and bury their war dead. At this point it is important to note that despite my use of terms like "refugee" or "displaced person" to indicate the civilian populations pushed into transit by wartime violence (as well as their comrades moving in and out of military status), Chinese terms for such persons are hardly fixed, either in the contemporary documents or in later scholarship. As Rana Mitter and Timothy Brook have shown, schemes of classification became central to the wartime programs of the Nationalists and the collaborationist governments, not simply for managing the flow of people but for maintaining a footing of total, political warfare. Nanmin 難民, "refugee"-literally a person under distress, duress, or difficulty—was the term of public art applied most often to the displaced by this period, whether their flight originated in wartime fears or the deprivation of natural and economic disaster. Yet neither public nor private discourse agreed that all displaced persons were nanmin. ${ }^{16}$ Therefore many who moved were not classified as nanmin - government officials and their families, soldiers (even though the life of the draftee and even the officer often intermingled with refugee status) - despite similarities in circumstances caused by the conditions of travel and shelter. Meanwhile the displaced themselves sought to control the nomenclature, demanding to be addressed as "righteous people" (yimin 義民) or reclaiming the value of nanmin for their own uses. Various other terms emphasizing loyalty-increasingly political rather than national—came into official usage. Nanbao (難胞, “refugee compatriots") was first applied to the residents of Japanese-seized territories in the northeast, then by "downriver people" (xiajiang ren 下江人) in the Nationalist interior to fellow-provincials in occupied zones, and finally as a political and native-place term of art during the Civil War. Such usages heavily influenced the KMT's adoption of yibao 義胞 (“loyal compatriot") during the Cold War to various groups, most notably the Dachen refugees discussed in the later part of this paper. ${ }^{17}$

This broad process was refracted, if not precisely reflected, in the system by which the Nationalist government provided selective burial assistance and death honors to parts of a population only. In something of an inverse as well as a byproduct of the way in which, Adam McKeown has argued, border-crossing procedures became ritualized as well as systematized under the US system of Chinese exclusion and other global migration laws specific to Asians, here ritual became systematized and subsumed under

\footnotetext{
${ }^{16}$ Mitter, "Classifying Citizens"; Timothy Brook, Collaboration: Japanese Agents and Local Elites in Wartime China (Cambridge, Mass.: Harvard University Press, 2005).

${ }^{17}$ See the round-up of contemporary accounts of refugee experiences in Lary, Chinese People at War, 5659. Janet Y. Chen, Guilty of Indigence: The Urban Poor in China, 1900-1953, (Princeton: Princeton University Press, 2012), and "Will the Real Refugees Please Stand Up? War, Revolution and the Politics of the Subei Refugee Crisis, 1940-1948," Twentieth-Century China 38:2 (May 2013), 99-118; Lary, Chinese People at War, 32-40; Liu, "A Whole Nation Walking," 228. Chen describes the deployment of yimin and nanbao as terms of political and moral art by and against Subei refugees in Shanghai. The effects of civil conflict and Cold War politics on the politicization of refugees as it affected diasporic communities is increasingly well studied; see Him Mark Lai, Chinese American Transnational Politics (Urbana: University of Illinois Press, 2010), chapter 5, as well as the introduction by Madeleine Y. Hsu; and Hsu, The Good Immigrants. A recent effort to theorize the integration of Taiwan's 1949 migrants into the larger history of Chinese diaspora is Dominic Meng-Hsuan Yang and Mau-Kuei Chang, "Understanding the Nuances of Waishengren: History and Agency," China Perspectives 2010:3, http://chinaperspectives.revues.org/5310.
} 
border-crossing procedure as a result of war. But governmental processes coexisted with social rituals of moving and burying the dead, enacted at various levels ranging from the trans-regional to the familial. ${ }^{18}$

\section{PROCESSING, SORTING AND DEPOSITING THE DEAD}

The Japan war presented new issues of scale and distance when it came to burying even the civilian victims of bombing, sickness, fatigue, or direct attack. In places like Jiangsu, charities of late-Qing origin (shantang 善堂 as well as native-place associations) continued to bury the needy, augmented by the burial corps of redemptive societies like the Red Swastika Society (Shijie hong wanzi hui 世界紅乙字會, an outlet of the society Daoyuan 道院); new charities like the Chinese Red Cross; and other religious groups such as branches of the Buddhist Association. Viewed from certain angles, the resources of such non-governmental organizations were challenged by the scope of the war, and by the encroachments of the nation-state. Much depends on geographic perspective: a comprehensive survey of Shanghai charities in 1946, for instance, found a number of organizations reassigning resources from burial and coffin transport to medical services to meet urgent needs. ${ }^{19}$

But investigations across regions, looking precisely at the problem of population movement, repatriation, and the reconstitution of community from a ritual as well as physical perspective shows that native-place associations (as well as burial corps, certainly pertinent but outside the scope of this paper) remained important throughout the war and postwar. Moreover, government personnel depended on their services, so much so that eventually they realized that they must imitate them in order to claim similar spiritual authority in the process of reconstruction.

Burial and reburial constituted a major element of this dependency. In Chongqing, public health officials mobilized workers to help collect bodies of bombing casualties and victims of disease and the elements, but it was the comparatively tiny Chongqing $\mathrm{Mu}$ nicipal Committee for the Transport and Burial of Scattered Bodies 重慶市浮露屍殹運 埋委員會 that did the work of encoffinment, finding the right tides and times to boat the corpses across the Yangzi, and burying them at the relatively remote Heishizi village in the Jiangbei district. With a staff of 25 to 30 (most of whom were boatsmen) and a minimal budget - especially when compared to that for other government services - the committee depended on local charitable organizations to provide the coffins, straw mats, and other burial materials. In 1943, therefore, thirty-two local shantang provided the committee with nearly a thousand coffins. Such cooperation was in keeping with the 1939 government plan for dealing with the city's air raid victims, which explicitly called for the assistance of the shantang and local elites, as well as the Red Cross and the Red Swastika Societies, for the care of the dead and the living in Chongqing's streets and cave shelters. ${ }^{20}$

\footnotetext{
${ }^{18}$ Adam M. McKeown, Melancholy Order: Asian Migration and the Globalization of Borders (New York: Columbia University Press, 2008), chapter 9.

${ }^{19}$ Such is the argument of Lu Liu's thesis, for example, which puts forth the idea that the war proved a decisive turning point in the rise of nationalism and the decline of the power of native-place associations. Xu Wancheng 許晚成, Shanghai cishan jiguan gaikuang 上海慈善機關概況 (Shanghai, 1946).

${ }^{20} \mathrm{CMA}$ 0064:5:108, 265-7; 0053:13:162, 90-96, 98-100; 0061:15;4019, 169-125; 0053:2:1124:65-67-1.
} 
Giving war dead — here we are talking mostly about civilian dead-a seemly burial in a timely fashion was one thing. In other words, this was mai 埋, the naked act of putting something under ground. Interring them properly, at home, with ritual (zang 葬), was another matter. This is an important context for understanding the role of native-place associations after the war. Bodies had to remain in place in the gathering points of the displaced, such as Chongqing, until hostilities ceased, and then it turned to the organizations with networks and resources to move them home. These circumstances were at first glance not so unusual in the history of native-place associations-indeed, this was what, in part, they were made to do-but the degree, number, and concentration of bodies and therefore the task at hand was heightened by the war. The meaning of the task, I would argue, was also heightened. This is harder to prove overtly from the evidence, but it is a reason to consider ritual as well as overt verbal statements (i.e., writing or speech) as expressions of emotional or moral stances. Consider that the majority of deaths during the war were - as far as we historians can see-unrecognized by family ritual. Despite widespread efforts to set up martyr shrines 忠烈祠 that honored high ranking officers, most soldiers were buried in haste on the battlefield. This is what the very scant literature on the subject tells us. The process of identifying even civilian victims of wartime violence could be difficult, and in cities such as Chongqing the zealous efforts to prevent the spread of communicable disease sometimes took precedence. The best chance at dying during this war and being recognized, it is sad to say, was to be very young or very old, or to die in a hospital.

Such was the case of Yi Shugui, one of the many "downriver" people who labored in Chongqing's factories. After she died of an unspecified illness, her employers at the Number Four Textile Factory wrote the Wuxi-in-Chongqing Native-Place Association in April of 1942 asking that her coffin be kept in their cemetery (公墓), until such time as her Shanghai family could retrieve it. ${ }^{21}$ The Association complied, burying her body in its Chongqing cemetery.

When it came to management of the dead, native-place associations provided several important services. Storage of the coffin until it could be transported, and then arrangement of that transport, was of course the most significant. The Wuxi association maintained a cemetery in Chongqing, as did the Guangdong association and others. The shift from the more typical practice of coffin storage (which some Chongqing groups did attempt) to temporary interment in a native-place cemetery can be attributed to the Nationalist government's zealous public health measures in its wartime capital. Official prohibitions against coffin storage (especially in temples and charitable halls, where they were held in numbers) had been in place under the prewar Nanjing regime; now they were revived with additional intensity as part of the wider disease-prevention efforts to remove the exposed dead from the streets and public spaces of Chongqing. ${ }^{22}$

\footnotetext{
${ }^{21}$ CMA 0234:1:42, 49. 1942.4.27.

${ }^{22}$ A sample February 1944 municipal order to clear out more than twenty coffins stored in a temple since the beginning of the war can be found in CMA 61:15:1875, 58-61 (Feb. 2, 1944, and Apr. 20, 1944). For the broader context of wartime public health in Chongqing, see Nicole E. Barnes, Protecting the National Body: Gender and Public Health in Southwest China during the War with Japan, 1937-1945 (PhD diss., Univeristy of California, Irvine, 2012), 417. Retrieved from http://search.proquest.com/docview/1112073960? accountid=13314.
} 
Thus the removal of bodies on their way to reburial was additionally complex. Each step entailed auxiliary ritual acts and financial preparations. Under "ordinary" circumstances, bodies would be kept until a calendrically auspicious time for their transport. When great distance was involved, as in the case of the return of Chinese migrants who had gone from southeast China to northern California in the nineteenth century, consultation of the almanac had to be overlaid with complex logistics. This resulted in a process Elizabeth Sinn calls "freightization of the dead" (a process eased by the Lingnan custom of secondary burial-thus in these cases boxes of bones could be sent as well as encoffined corpses.) In these trans-Pacific shipments, hundreds of sets of bones might be carried on one ship, to be held in Hong Kong by various charities that offered storage and transshipment to south China. In the case of Shanghai in the Republican era, the distances involved were not so great, yet the real estate that the native-place coffin storage facilities occupied became a notable feature of the urban landscape, reflecting the economic and regional diversity of migration in the city. Finally, movement at each point of the process necessitated ritual, whether it was the more modest employment of a fengshui master or the holding of a large-scale jiao 醮 offering ritual for multiple coffins, requiring the hiring out of various ritual specialists. ${ }^{23}$ The task of caring for the displaced dead, therefore, commanded substantial resources and long-term planning.

\section{The Wuxi Coffin Boats}

As early as the spring of 1945, however, displaced Jiangsu natives in Chongqing were planning to send not living refugees, but dead ones, back east. In minutes from a meeting of May 11, 1945, members of the Wuxi-in-Chongqing Native-Place Association eagerly anticipated the spread of the Allied victory to western China and foresaw the work ahead. For instance, it was decided that members who returned to find that their homes had been occupied by military forces or youth camps or destroyed ought to be able to seek legal assistance from the association. And, as soon as the line of victory reached the wartime capital, the group would put out a call for members to register to send their relatives' and friends' coffins back east. The following month, association leaders convened a "reconstruction conference" in which they started apportioning responsibility to important members for getting "downriver" people back home. Though these plans took months to come to fruition, wartime native-place associationsformed with the express purpose of "maintaining contact with," "developing intelligence of", and "furthering the reconstruction of" the home place-kicked into action. Nativeplace networks still provided a material and ritual service that at this point the government was unwilling or incapable of doing. ${ }^{24}$

\footnotetext{
${ }^{23}$ Elizabeth Sinn, Pacific Crossing: California Gold, Chinese Migration, and the Making of Hong Kong (Hong Kong: Hong Kong University Press, 2012) 268, 281-82; Bryna Goodman, Native Place, City, and Nation: Regional Networks and Identities in Shanghai, 1853-1937 (Berkeley: University of California Press, 1995), 252-53. Janet Chen (2013) also points out that - in a particularly poignant turn of events-Shanghai coffin storage facilities served as makeshift shelters for wartime refugees.

${ }^{24}$ Wuxi-in-Chongqing Native Place Association 無錫旅渝同鄉會, minutes of board meeting 6:2, May 11, 1945, and Reconstruction Conference, June 13, 1945; CMA 0091:2:5, 9, 12-13. Other native place associations performed this service for members-for instance the Ningbo association in Chongqing. Zhong Yanyou 鍾醠
} 
The Wuxi-in-Chongqing association became one of the primary transporters of encoffined corpses back upriver in the immediate postwar period. The association sent five boatloads of coffins by wooden boat and barge during the first ten months of 1946 . There are about 160 extant requests in the Chongqing archives for permission to send a coffin on one of these trips, but given damage to the files and the fact that some trips comprised 80 or more coffins apiece, the total number sent was likely much higher, probably around 400. A mere handful of those in the records (around ten) were destined for Wuxi itself. Instead, requests reveal that a wide variety of private persons, government officials, and even military personnel asked that the association help transport the bodies of relatives and friends to places throughout Jiangnan, Anhui, and sometimes as far north as Hubei.

Once victory was assured and the possibility of transport back to east China opened, these transports were arranged with remarkable rapidity. The corpses followed or sometimes overtook the living on the trip upriver in winter 1945-46, but via different official conduits. For instance, undated draft correspondence of the association chair from very late 1945 requests the aid of CNRRA in obtaining permission for a wooden boat containing 60 (living) persons to sail from Chongqing to Nanjing. The flag and individual permits for this return-refugee boat had to be obtained from the Ministry of Social Affairs. Boatloads of corpses, on the other hand, were treated as cargo, and thus subject to the strict oversight of riverine transport in the immediate postwar era. Individuals had to apply certifying the name and details of the deceased (including cause, place of, and age at death) in order to receive specific permits of military and police passage. Then the shipment as a whole required approval from municipal police and customs authorities as well as from relevant stations along the route. Little wonder, then, that the trips could take more than seven months to reach their final destination, and that basic transport costs per coffin doubled between February and October 1946, from Y25,000 to Y50,000. ${ }^{25}$

The business of repatriating bodies was both important and perilous, and the Wuxi association initially kept the transports secret from the public. First, it was a touchy subject. It took some doing, for example, to find boatmen willing to deal with corpses, and the logistics of sending boatloads of coffins at a time when military and governmental transshipment took priority cannot be discounted. In addition, the trip itself posed dangers. In August 1946, the fifth coffin transport hit rocks in Zhong county 忠縣, Sichuan, and sank, three bodies tumbling irretrievably overboard. The consequences took months to sort out. These only began with scrambling to finance the onward journey and sort out

\footnotetext{
敒, Zhengzhi xing yimin de huzhu zuzhi-Taibei shi de waisheng tongxiang hui 政治性移民的互助組織: 台北 市之外省同鄉會, 1946-1995, ed. by Lin Manhong and Wen Jiayin 林滿紅主編; 翁佳音副主編 (台北縣板 橋市 : 稻鄉出版社 1999), 252.

${ }^{25}$ Wuxi-in-Chongqing Native-Place Association to Relief and Reconstruction Office, draft, CMA 0091:1:4, 52. This was the base amount per coffin charged by middlemen who arranged the boat transport. The trips incurred other expenses, including the cost of longshoremen and ambulances to transport the coffins (all the better to meet the standards of public health and propriety). Most incidentals seem to have been initially borne by the association rather than the families of the deceased, who nonetheless paid a fee for the transport. By the time of a planned sixth transport in the spring of 1947, which was meant to clear out the association's Chongqing cemetery so that the land could be sold, inflation had caused this fee to spiral to Y400,000 per coffin (Wuxi-inChongqing Native Place Association, board meeting minutes 7:2, 8/9/46 and 7:6, 3/3/47. CMA 0091:2:5, $54-56,81)$.
} 
the legal matters surrounding the conduct of those on the scene. The Wuxi association and those in charge of the boat also owed a moral debt to the families of the lost corpses, one which had to be repaid in monetary compensation and also in collective responsibility, which, the directors agreed, "we all shared."26

Second, the first coffin shipments were also likely kept secret because people were clamoring to bring their relatives home, and few resources existed to help them do so. When in October 1946 the association chair finally made the trips known to the broader public, the Wuxi press immediately called on other native-place associations to apply to his group for aid in bringing their fellow villagers home. The list of those utilizing the association's services, meanwhile, included officers of the KMT Politburo's secretariat, bureaucrats in the Military Affairs Commission and other branches of the military-political structure, and an assortment of academics and businesspersons. At this point of the postwar period, clearly the native-place association offered a better means to thus reunite a family than did official channels. ${ }^{27}$ And yet, the transports also show that the well-established mechanism of native-place-based resettlement of bodies broadened its social reach in the postwar years. The Wuxi shipments brought not only the bodies of social elites and sojourning males back home, but also those of young female factory workers such as Yi Shugui.

The native-place association records do not reveal what the process of repatriation of corpses and reburial meant to people, and why they went to such great lengths to pursue it at a time when the physical return of living bodies to hometowns was itself still so unsure and difficult. In the absence of first person testimony, however, something can still be deduced from actions, policies and context. Party functionaries, government bureaucrats, bankers and tradespeople, and transferred academics and factory clerks sent back the bodies of parents, spouses, siblings, and sometimes young children who had died mostly from disease, and occasionally during air raids. These had the benefit of being relations and friends whose time, place, and means of death was known. Moreover, their displacement could be remedied. In addition, recalling the moral narrative presented in the Ding genealogy, properly constituting a locality or family tomb or graveyard-by physical burial and by ritual—could be seen as an essential part of restoring normalcy.

Yet it was not only these relatively privileged displaced persons who, having preserved their family units to some extent during the war, sought to continue to preserve them as part of returning to the home place after it. There were also several permit requests signed by the local bao or jia [保, 甲—local government units] heads pleading for the association's help in returning the bodies of Jiangsu or Anhui natives, wartime residents of the locality who had died some years earlier and had been temporarily interred nearby. In some cases relatives had come or written looking for their husbands' or sons' bodies. But in others, it was the local Sichuan official who himself took the initiative-perhaps out of moral principle, social connection, or as a way to rid his community of a troublesome presence. ${ }^{28}$

\footnotetext{
${ }^{26}$ Wuxi-in-Chongqing Native-Place Association, minutes of emergency meeting of the standing committee, 10/3/46. CMA 0091:2:5, 68-9.

${ }^{27}$ Wuxi-in-Chongqing Native-Place Association, minutes of board meeting 7:5, 10/17/46. CMA 0091:2:5, 78a. Wuxi-in-Chongqing Native-Place Association, permits, coffin repatriation shipments, 1946, CMA 0091:2:1.

${ }^{28}$ Ma Jingqing to Wuxi-in-Chongqing Native-Place Association, CMA 0234:1:149:174-75, 19XX, 6.14.
} 
It must be emphasized: the Wuxi bodies had the virtue of being identified, and their places of temporary interment known. Their repatriation not only held the potential of helping to reconstitute a family and a community back east, at a time when too many people did not know where their relatives were buried, whether they be men fallen on the battlefield or friends and family taken by bombs, disease, or military attack to an unmarked or mass grave. What was more, their removal from Chongqing held the potential for helping reconstitute those local communities as well. In a city peppered with "white bone pagodas" (bai gu ta 白骨塔) marking the collective graves of air raid victims, it would be understandable if local authorities were anxious to promote the business of spiritual pacification by removing the displaced dead and sending them to their proper homes. In this sense Chongqing and its environs, riddled with temporary and hasty graves as well as native-place-association cemeteries explicitly created during wartime-had stretched the boundaries of the Chinese pattern of sojourning and bone or coffin repatriation of migrants. ${ }^{29}$

Bodies and the Nation-Body

Given the dependency of the human Nationalist infrastructure on private groups like the Wuxi-in-Chongqing Native-Place Association for aid in physically and psychically reconstituting upriver communities, it is not surprising that the government itself soon desired to step in to serve that role for national goals. Thus the Nationalist government eventually provided burial funds of its own, but only to certain populations. This had been presaged during the war: one means of keeping essential personnel on hand-“at home", when one wanted them at home-was to provide burial funds for their families, as the Fujian provincial government did in 1944 for teachers and doctors in official employ as well as provincial officials. In late 1946 the national government began offering support to government officials returning to Nanjing to bring the bodies of their family members back with them. As the postwar quickly melded with civil war, this privilege was extended to essential transport personnel. Railway and shipping workers were needed to complete the process of restoring the east China Nationalist power base and also combating the $\mathrm{CCP}$ - a fight that naturally put them in the line of fire. Families of managers on the Nanjing-Shanghai Railway received particularly generous compensation for coffin transport and burial expenses (those of ordinary workers and railway police were compensated at half the level). Rates had to be adjusted frequently to keep up with postwar inflation. ${ }^{30}$

Coffin transport and burial was also a means of reincorporating the lost into the body politic. The Nationalists coupled this action with the quintessential postwar acts of border redrawing and repatriation. Thus the third main class of persons provided with government funds for corpse transport and burial were the former subjects of the Japanese

\footnotetext{
${ }^{29}$ Elizabeth Sinn demonstrates how this process of corpse repatriation functioned in international migration as well; "Moving Bones: Hong Kong's Role as 'In-Between Place' in the Chinese Diaspora," in Cities in Motion: Interior, Coast and Diaspora in Transnational China, edited by David Strand and Sherman Cochran (Berkeley: University of California Press, 2007), 247-71; and Sinn, Pacific Crossing, chapter 7.

${ }^{30}$ Minzheng jianbao 民政簡報 1944 (18). National Government Archives, Academia Historica 6953A. Yunwu zhoubao 運務週報 no. 16 (1946), 319, and no. 48 (1947), 1402.
} 
empire in China's northeast. Their process of "regaining their citizenship" (huiji 回籍) or repatriation was tied to a strong encouragement toward onward migration to China proper, based on an assumption that their families had migrated to Manchuria in the recent past. Hence CNRRA was prepared to issue burial or reburial subsidies in exchange for certification as a citizen of the Republic of China. ${ }^{31}$

Thus in contrast to the rural resettlement programs of the early part of the Japan warwhose leaders regarded the threat of death as incentive for people to abandon home permanently without considering the ties bound by the past dead — organizers of postwar life recognized that burial could be used as a lure to reconstitute place along the lines they preferred. But although funds were offered, by and large the state declined to provide comprehensive assistance for the means of transport. In some cases rail passage could be arranged, but this became increasingly challenging as the civil war ate up transportation resources. Thus the mechanisms of the native-place associations and the philanthropies still remained essential.

Thus the dead proved extremely difficult for government authorities to manipulate. The connections between the dead and the home place did begin to loosen and fray under the strain of wartime and postwar displacement, meeting their ultimate challenge with the separation of 1949. But the dead remained a regular part of the wartime and postwar everyday, challenging political reinterpretation. The remainder of this paper will examine how the stakes for the war and refugee dead were raised in early martiallaw-era Taiwan. In the case of the First Taiwan Strait Crisis, fervent attempts to construct a model group of "loyal compatriots" masked distinct problems in settling the displaced.

\section{MARTYRS, HEROES, SONS, DAUGHTERS, GHOSTS}

The Japan war unsurprisingly brought with it a growing number on all combatant sides of military memorials honoring "loyal martyrs" (zhonglie 忠烈 or lieshi 烈士). Indeed, these had been increasing in popularity in China for some decades, in the form of military memorials as well as secular shrines to ethno-nationalist symbols such as Confucius, Yue Fei and Guandi, and the political family of the KMT itself, with Sun Yat-sen as father. ${ }^{32}$ Thus a notable wartime phenomenon was the continued assertion of local interests in such shrines versus central authorities who wished to claim control.

Surprisingly, the interest of the central authorities in martyrs' shrines did not seriously get underway until late 1939 and early 1940, and this began largely at the urging not of Chiang Kai-shek but of Feng Yuxiang, a man eternally interested in ritual proprieties. At that point local authorities (such as they were, military or civil) were requested to report

\footnotetext{
${ }^{31}$ Executive Yuan archives, February 1946; Academia Historica 062:649.

${ }^{32}$ See Prasenjit Duara, "Superscribing Symbols: The Myth of Guandi, Chinese God of War," Journal of Asian Studies 47 (Nov. 1988), 778-95, and Rescuing History from the Nation: Questioning Narratives of Modern China (Chicago: University of Chicago Press, 1995); Susan Glosser, Chinese Visions of Family and State, 1915-1953 (Berkeley: University of California Press, 2003); Charles Musgrove, China's Contested Capital: Architecture, Ritual, and Response in Nanjing (Honolulu: University of Hawai'i Press, 2013); Rebecca Nedostup, Superstitious Regimes: Religion and the Politics of Chinese Modernity (Cambridge, Mass.: Harvard Asia Center, 2009), chapter 7; and Linh Vu's forthcoming PhD dissertation in the Department of History, University of California, Berkeley.
} 
on the condition of their shrines. These surveys revealed not only that a number of local entities had gotten going without the center's prompting, but that the definition of a “loyal martyr" (zhonglie 忠烈) varied widely. Sometimes the lists can be read as reflections of the wartime situation of the province: that the Zhejiang martyrs' list is just about entirely military, for example, may not only reflect the local authorities' priorities, but also its only clear source of pride in a time when the civilian government was reduced to a rump organization fleeing occupation. In other cases it is a strong sense of place that defines ideology. The Henan shrine list, lengthy and detailed, iterates the contributions of civilian officials killed while on duty. Thus the rectitude of the righteous civilian means as much as the sacrifice of the the brave warrior. In this Henan's shrine resembles more closely imperial-era shrines to local former worthies of the imperial era, except that in its expanded scope, a clerk could be considered for honors as well as a county head. ${ }^{33}$

So were these shrines meant to commemorate the sacrifices of local people, and thus tie that community together? Would their families have a ritual role to play, if their spirit tablet was enshrined therein? The shrines, after all, contained spirit tablets and did not resolve the problem of burial. But in some cases where the body was missing or destroyed, the potential difference could become elided. And as the war progressed and eventually shifted into civil conflict, it became more apparent that national leaders also wanted to take a more central part in the proceedings, and gather the local and familial into the nation. ${ }^{34}$

Wartime made even developing national shrines an unstable process, however, at its most basic level. Where was the home seat of the nation and thus its national spirit? How long could a national spirit (or its component heroic martyrs) go untethered and unrecognized while the country awaited the retaking of the proper national capital? These were topics much debated in Chongqing during the early 1940s, and again in Taipei of the 1950s and 60s. In 1941 officials at the Ministry of Interior reassured themselves that "the National Government's move to Chongqing is of a temporary nature; because Chongqing is a secondary capital and not the main capital, it seems permissible to take up the topic of constructing a Capital Martyrs' Shrine on a temporary basis." They proceeded to labor mightily on the project, first battling local Daoists to take over a Guan [Di] - Yue [Fei] Temple for the purpose, in a strategy typical of the previous decade, and then when that failed engaging their own architects to draw up plans for a new structure. Yet perhaps the refugee status of this shrine continued to haunt the officials, because it never was completed, and at war's end the decision was made to return attention to the "main capital," Nanjing. ${ }^{35}$

A significant transformation had happened in the interim, though, and it was one that would continue to have repercussions in the civil war and postwar eras. During the 1930s ritual revival in the KMT Chiang Kai-shek had been merely one figure among many

\footnotetext{
${ }^{33}$ Ministry of Interior archives, September 2, 1939, Academia Historica 129:313. Ministry of Interior archives, March 21, 1940, Academia Historica 129:262.

${ }^{34}$ A contrast can be drawn to the Chinese Red Cross's efforts to establish common burial grounds during earlier conflicts such as the 1911 Revolution, where the universal and national was combined with connections to locality and family ritual. Caroline Reeves, "Grave Concerns: Bodies, Burial and Identity in Early Republican China," in Cities in Motion, edited by Strand and Cochran, 27-52.

${ }^{35}$ April 7, 1941, Archives of the Executive Yuan, Academia Historica, 062:533.
} 
speaking of the need to seek China's “original moral tradition” (guyou daode 固有道德), particularly in its past and present martial and ethical heroes. Political leaders such as Dai Jitao, Feng Yuxiang, Shao Yuanchong, and Lin Sen had been far ahead of him on this front. During the Japan and civil wars, however, one can see clear moves where Chiang increasingly asserts the role as chief moralist and chief ritual officiant for the nation, and the officials around him follow along. Plans for the second version of the Chongqing martyrs' shrine, designed internally by the Ministry of the Interior, included a telling detail: the elevations of the main hall showed a figure for scale outside the central door, a figure dressed in a familiar military cape and officer's cap. Chiang's presence was now assumed, and the national leader figured most importantly in the plan, even more so than the spirit tablets of the dead. ${ }^{36}$

Later in Taiwan, Chiang's personal will figured even more strongly in the transformation of the Taipei Martyrs' Shrine into a national shrine. This was an even longer process, one that involved first converting a Shinto shrine of the Japanese era into a site more in the Nationalist mold — as the KMT did around the island - and then debating the propriety of local or national management of the Taipei shrine for almost two decades. By the time the shrine was reconstructed on a large scale into its present state, removing lingering Japanese traces and finally put under national control as something approximating a capital shrine, officials were regularly consulting Chiang Kai-shek as a matter of course on every aspect of the plan. ${ }^{37}$

The Widows of Yijiangshan

The territorial split of 1949 decentered the locus of national power in ways that seemed to some Nationalists to present a painful yet familiar pattern, even if geopolitical hindsight and a broader understanding of Taiwan's pre-KMT history now makes such a outlook seem hopelessly limited. One response to the destabilizing of the seat of national government amid continued military mobilization was to gather the spirits of the soldierly war dead even closer. Chiang Kai-shek personally arrogated power and responsibility to himself as chief ritual officiant. Such measures meant to counteract by fiat the instability the civil and Cold wars created, dividing community and family as well as country. But this very instability meant that moments could arise when authority to speak for and succor the dead was challenged. One notable example occurred in the aftermath of the First Taiwan Strait Crisis (1954-55).

This is an instance when the consideration of the place of the dead yields a possible counter-narrative to the hyper-patriotic rendering of events that was carefully constructed at the time, and has been assiduously cultivated in the decades since. ${ }^{38}$ The Nationalists'

\footnotetext{
${ }^{36}$ Plans dated February 1944, Archives of the Executive Yuan, Academia Historica, 062:533. Also see Nedostup, Superstitious Regimes, and "Two Tombs: Thoughts on Zhu Yuanzhang, the Kuomintang, and the Meanings of National Heroes," in Long Live the Emperor! The Uses of the Ming Founder Across Six Centuries of East Asian History, edited by Sarah K. Schneewind (Minneapolis: Society for Ming Studies, 2008), 355-390.

${ }^{37}$ Files on renovation of Yuanshan Martyrs' Shrine, 1958-69, Archives of the Office of the President, Academia Historica 2212101/10/1.

${ }^{38}$ The definitive research on the social and political evolution of the Dachen islanders on Taiwan has been conducted by a research group led by Chang Mau-kuei, much of which is collected at two Academia Sinica
} 
defeat in battle around islands it had continued to hold off the northeast coast of Zhejiang resulted in a mass military and civilian evacuation: several thousand servicemen; the surviving families of the more than 700 (out of 1,000) guerillas, regular forces, and nurses killed on the pivotal battle island of Yijiangshan 一江山; and as many as 18,000 residents of the Dachen island group 大陳列島, Nanji island 南鹿山, and several other small neighboring islands. Transportation was augmented by the US Seventh Fleet, with logistics enabled by the US Marine Corps. ${ }^{39}$ Such aid not only marked a new stage in the development of the Cold War in East Asia and US-ROC relations. It also enabled the visibility of the Yijiangshan and Dachen refugees on the world stage. Still and newsreel photographers from both Taiwan and around the world were positioned on Dachen, onboard ship, and at Keelung port to capture the arrival of the refugees. Government snapshots from the Central News Agency highlighted army nurses aiding mothers and children, soldiers guiding the elderly, and Madame Chiang Kai-shek and her daughterin-law Faina Chiang Fang-liang distributing rations to the rosiest-cheeked waifs that could be found. Claims for the identity of the Dachenese as Communist-hating patriots had already been burnished by visual representations of the intense militarization of the islands in the period leading up to the strait crisis, when the distribution of political slogans and citizenship cards around the Dachens had been punctuated by personal visits from Chiang Ching-kuo and Chiang Kai-shek. ${ }^{40}$ Although the British and

databases: “Zhuisou Dachen: shehui wenhua wang”追尋大陳: 社會文化網, http://dachen.ios.sinica.edu.tw/, and the newer “Taiwan waisheng ren—-shengming jiyi yu xushi” 台灣外省人 一 生命記憶與敘事, http:// ndweb.iis.sinica.edu.tw/TWM/Public/index.html. On the state's role in shaping identity formation for the Dachen displaced during subsequent decades, see Chen Wei-hua and Chang Mau-kuei 陳緯華、張茂桂, “Cong 'Dachen yibao' dao 'Dachen ren': shehui leishu de shengcheng, zhuanbian yu yiyi”, 從「大陳義 胞」到「大陳人」：社會類屬的生成、轉變與意義〉，Taiwan shehui xue 27 (2014), 51-95.

${ }^{39}$ There is some contradiction among sources overall regarding the total number of civilians evacuated, but 18,000 is the iconic number claimed by the Nationalists at the time and repeated in Dachen histories and by the evacuees themselves ever since. Bruce Ellemann's account of the evacuation, drawn from US military sources, for example, puts the number of civilian evacuees at only 11,000 (Bruce A. Ellemann, Taiwan Straits: Crisis in Asia and the Role of the US Navy [Lanham, Md.: Rowman and Littlefield, 2015], 62-65). The ROC Ministry of Defense, on the other hand, put the population of the archipelago at the time of evacuation at 14,416 (Guofang bu shizheng bianyiju 國防部史政編譯局, Guojun waidao diqu jieyan yu zhandi zhengwu jishi [vol. 2] 國軍 外島地區戒嚴與戰地政務紀實（下）[Taipei: 國防部史政編譯局, 1996], 888, cited at http://dachen.ios. sinica.edu.tw/moving.htm). 17,132 residents of the island registered for evacuation after Yijangshan fell in later January 1955, effectively receiving a certification as ROC citizens that, presumably, many had formally lacked (Chen Jen-ho 陳仁和, Min zhi gui ren: yi wan ba qian ren mie jia xuan ziyou 民之歸仁: 一萬八千 人毀家選自由 [台北中和: 大陳地區文獻委員會, 1977], 149). As for military personnel, a CIA report on the eve of the crisis in the fall of 1954 put the Nationalist forces in Dachen at 15,000, although according to a later report-based on information relayed by the US Military Assistance Advisory Group (MAAG), some guerrilla forces were maintained in Nanji and other positions after the civilian evacuation in February 1955. Central Intelligence Agency, Office of Current Intelligence, "The Chinese Offshore Islands," September 8, 1954, CIA-RDP79R00890A00400050004-4; and Central Intelligence Agency, NSC Briefing February 16, 1955, CIA-RDP80R01443R000300250007-6; CREST, National Archives at College Park, College Park, Md.

${ }^{40}$ The Chiangs made a well-documented visit to the Dachens on May 8, 1954; see, among others, Chen Jenho 陳仁和, Minzu zhengqi: Yijiang yishi xue, Dachen minzhong xin 民族正氣: 一江義士血, 大陳民眾心 (台北中和: 大陳地區文獻委員會, 1975) and Min zhi gui ren. Laudatory news accounts in various Taiwan newspapers, including the Central Daily News (Zhong yang ribao 中央日報), Xin sheng bao 新生報, Zhonghua ribao 中華日報, Lianhe bao 聯合報 and Minzu wan bao 民族晚報, are collected in Xin xingshi yu xin bushu「新形勢與新部署」（台北: 海外出版社, 1955）31-62. A wealth of detail can also be found in 
American press was certainly willing to foster the anti-Communist narrative, it also sympathetically portrayed the suffering of displaced civilians, a second narrative entirely in keeping with the message of the 1951 Refugee Convention and the post-1945 humanitarian international refugee regime as a whole. A British Pathé newsreel, for example, used footage, presumably supplied by the CNA, that showed Nationalist soldiers pulling and prodding refugees laden with belongings so that their faces and name tags were revealed on camera. Pathé's dramatic narration made the situation sympathetic, yet seemingly inevitable:

It was a scene all too familiar in this half century. We saw it recently in Korea. Before that, in almost every country in Europe. Still earlier, in Spain and Abyssinia. Men, women, and children on the run - their only crime, that they had made their homes in the paths of the machine of war. ${ }^{41}$

LIFE magazine ran two extensive photo essays on the crisis, featuring pictures by the lauded photojournalists Howard Sochurek and Horace Bristol, the former fresh from an assignment documenting the Vietnamese victory at Dien Bien Phu. Though sympathetic to the KMT side, the work of Sochurek and the Japan-based Bristol focused on the human costs of the evacuation. The first essay, "Faces of the Formosan Crisis," led off with a full-page shot of a weeping Yijiangshan widow as she walked ashore, infant in a quilt bundle on her back, surrounded by distressed women and children. Another shot by Sochurek depicted an expensive-looking coffin left behind on the shore. ${ }^{42}$ The extensive documentation of the Dachen evacuation thereby began to raise inadvertent questions. The conspicuous display of government largess for food, shelter, and clothing was all very well. But how would these other kinds of losses be redressed; how would such burdens be lifted?

To the Nationalist state and Chiang Kai-shek in particular, of course, a system was already in place to assimilate such losses. To begin, the dead of Yijiangshan, whose sacrifice was especially acute, would be honored as national martyrs, lieshi primes inter pares. This process, too, was comprehensively recorded in photographs, press, and other publications-which likewise revealed the tensions and fissures within. ${ }^{43}$

This was most evident at the first ceremony marking the martyrdom of the Yijiangshan dead, held on February 17, 1955-mere weeks after the battle and evacuation. The proximity to events meant that the ritual and symbolic proceedings could not easily be confined to national and military grounds, even though it was precisely those entities that sponsored the ceremony. Once again Chiang Kai-shek arrogated to himself the role of chief mourner, presenting incense before a crane-adorned funerary altar. The altar contained a collective spirit tablet for the "righteous and humane Yijiang martyrs," as well as six photographic portraits of individuals. Officers and soldiers made up the

He Zhengxin, "Dachen guo Taiwan - 1950 niandai xin yimin de ge an yanjiu” [Dachen goes to Taiwan: A case study of new migrants of the 1950s] (MA thesis, Tamkang University, 2005).

${ }^{41}$ British Pathé, "Evacuation of Tachens Ends" (1955), https://www.youtube.com/watch?v=qm7-XpLZI-E .

42،"Faces of the Formosan Crisis", LIFE 38 (1955), 26-33. This essay is uncredited, but the follow-up ran under Sochurek and Bristol's byline, "A Gamble that the Reds Won't Fight - and We Win," LIFE 38 (1955), $42-46$.

${ }^{43}$ The main record is He Dingxin 何鼎新, Yijiangshan xun guo zhong lie lu一江山殉國忠烈錄 (Taipei : 東 方出版社, 民國 46 [1957]); Chen 1977 and Xin yingshi also contain extensive reprints and information. 
bulk of the attendance, except for a small group of civilian aides in western suits (for the men) and for women, dark qipao with white mourning chrysanthemums in the style of New Life Movement funerary reform. All of these contrasted with the family members, who sat on the ground to the left of the altar. Many of these women and children wore hemp or rough white mourning clothing. Even the ones wearing their dark everyday clothing and caps are marked as rural, in comparison to the military men and urbane junior officials who surround them. Beyond the simple indicators of difference in class and native place, however, here two regimes of mourning met. One instated funerary offerings into the state commemorative ceremony as a means of incorporating the lost soldiers into the "big family" of the nation-state. In this the national leader naturally took precedence over natal family members as the mourner-in-chief. Solemnity and decorum was the marker of such ritual. In the other, wives mourned husbands, mothers mourned sons, and both instructed their children in how to mourn their fathers. Grief was not to be disguised or managed, but demonstrated as an integral part of the ritual proceedings, as well as a natural outcome of the situation. Thus a photograph of Chiang addressing the families, flanked by a reporter and photographers, reveals an array of faces in open demonstrations of emotion. Most of the adults do not raise their heads; at least two mothers hold infants in arms, expressions cast down, but a young woman in the center of the middle row of mourners, in dark clothing and not wearing visible traditional mourning, raises her eyes directly at Chiang Kai-shek, cheeks streaked with tears. If we follow Chiang's discomfited stare to the lower right corner of the frame, there one woman is staring balefully away from him, and at the camera. The gaze of these two women-among the only weapons available to them in the moment-augments the challenge to the state arrangements and most specifically to Chiang. The photograph cuts through the stage management that heavily determines the written record on the Yijiangshan martyrs, revealing emotions of war and displacement that cut through one form of ritual, and were expressed in another. ${ }^{44}$

By the time of the next ceremony, on January 20, 1956, the families were displacedliterally pushed to the very sides of the proceedings, with enhanced ranks of military and civilian officials taking their place. They did not feature in the photographic record, which was dominated by Chiang Kai-shek and Commander in Chief Sun Liren. ${ }^{45}$ The Yijiangshan martyrs grew in national myth, eventually earning a monument in concrete. This necessitated the shedding of ritual familial ties that might raise uncomfortable questions about their sacrifice or lost homes, or that would involve non-modernized, non-state mourning. The families were documented instead as recipients of state aid, via housing

\footnotetext{
44"President Chiang Chung-cheng [Kai-shek] mourns the loyal martyrs of Yijiangshan," February 1955, Chiang Kai-shek Presidential Archives, Academia Sinica 002-050101-023-204 and 002-050101-023-205. The photograph of Chiang and the families is also reproduced in Chen, Min zhi gui ren, and can be found along with the photograph of the altar at the online memorial site "Yijiang lieshi xunguo liushi zhounian jinian”一江烈士殉國六十週年紀念, http://www.ichiang60.org/web/SG?pageID=40976. The six photos visible at the altar but not fully identifiable presumably included Yijiangshan District Commander and Hunan native Wang Shengming 王生明. I owe a debt to Yu-chi Chang and Marc Moscowitz for helping me advance my interpretations of KMT funerary structure and this photographed encounter in particular.

45"Anniversary commemoration ceremony for Yijiangshan KIA," January 20, 1956, Chiang Kai-shek Presidential Archives, Academia Sinica, 002-050101-00025-194.
} 
allotments and education for the children. ${ }^{46} \mathrm{~A}$ useful contrast might be made to other military widows and mothers. Chiang's archives yield numerous photos from the same years of the presidential couple hosting the families of downed air force pilots at their homes in Shilin and Yangmingshan. The poised urbanity-all perms and qipao, children rarely present - of the air force widows, a group who socialized with Soong Mei-ling and were specially patronized by her, drew a sharp distinction to the Yijiangshan widows and children ${ }^{47}$ The inassimilability of the latter continued to be evident even in hagiographic publications such as Record of Loyal Yijiangshan Martyrs' Sacrifice for the Nation (1957), which consisted mainly of the by then rote displays of military power, patriotism, and state care. Reprinted photos of the families' grief-wracked faces stood uncomfortably beside attempts to extract patriotic testimony from the children in particular. Said one young son, "Daddy's body was eaten by the Commie bandits, but his spirit lives on!" 48 The transformation of the deceased from "Daddy" to an eternal spirit that the nation could honor was not only important for remaking a stunning defeat into a heroic tale. It was also necessary as a means of incorporating the new arrivals into the ROC on Taiwan, an ad-hoc political project that the First Strait Crisis forced the KMT to recognize might persist for some time.

Notably, then, the same volume highlighted eight noteworthy names among the 720 martyrs of Yijiangshan-versus the six individualized on the first commemorative altar-and concluded the list with a case of family sacrifice and return. Although the couple Chen Meiyuan 陳美圓 and Jiang Guihua 蔣桂花. were listed collectively under Chen's name, and described as "sacrificing themselves at the same time," it was Jiang's story that the volume told. Although she had only undergone a brief period of nursing training when the battle on Yijiangshan broke out, she requested to be sent early to the front lines to tend the wounded. "She left a daughter on Dachen, Chen Jufen 陳菊芬," the biography concluded, "who has already returned to Taiwan Formosa." 49 Generally speaking, however, tales of sacrifice and martyrdom are not meant for the kin of the martyrs, just as the memorials ultimately were not meant for the families. Their didactic value is intended for another audience. The Yijiangshan/ Dachen evacuation, in the way that crises do, made the prospect of a larger social obstacle evident to the political and military authorities. That was the possibility that Taiwan's many displaced persons - if not elites who considered themselves exiles, then persons further down the socio-economic ladder who were displaced in multiple ways-would not cleave to the island as a place or a polity because of home ties. By using Yijiangshan and Dachen as a proxy, the state began to address anew the problem of home, and of those left behind-including the dead.

\footnotetext{
${ }^{46}$ Chen, Min zhi gui ren, 195-98. The CCP fought back; the Beijing-based Chinese Red Cross alleged that the Nationalists carried out atrocities during the evacuation: see Calamity on Dachen [Dachen hao jie 大陳浩 劫] (Beijing, 1955), which, ironically, copied many of the photos seen in LIFE.

${ }^{47}$ This is not to say that air force widows did not grieve. Their public image, however, was managed to exclude such expressions. Indeed, it would take the seminal works of "mainlander" fiction to probe the emotional lives of such communities; notable in this regard is Pai Hsien-yung's short story "A Touch of Green" (Yi ba qing 一把青), in Taipei People, trans. by the author and Patia Yasin [Hong Kong: Chinese University Presss 2000], 37-79.

${ }^{48} \mathrm{He}$, "Dachen guo Taiwan," 1957.

${ }^{49} \mathrm{He}$, "Dachen guo Taiwan," 162.
} 
Theater served as a primary mechanism for the wider dissemination of political ideals and arguments in postwar Taiwan. Drawing from the techniques of mobilizational drama developed in both Nationalist- and Communist-controlled areas during the war with Japan, the political theater of KMT Taiwan was supported heavily through state subsidy and promotional organizations such as the Chinese Cultural Awards Committee. As Liwen Wang points out, many plays rehearsed the history of civil warfare and separation the audience members had just lived through, albeit sometimes through invented rather than actual scenarios. ${ }^{50}$ One such production was devoted to the topic of the "loyal comrades" forced to flee Dachen. The play was published in March 1955 by Gao Qian 高前, who was to go on to build a career in the theater and teleplays, but at this time was writing mainly for the extensive military entertainment system. The script appeared to coincide with programs to resettle the Dachen islanders-who were overwhelmingly fishing families-in farming-centered "new villages" scattered around Taiwan island.

“Farewell, Dachen!" [Zai huiba! Dachen 在會吧! 大陳] had a cast of characters out of a New Culture-era domestic novel. It revolved around a family consisting of a traditionalist and money-minded father and mother; an elder son who tended to butter up the old folks; and his more revolutionary-minded younger brothers and sisters, including one sister who joined the Nationalist guerilla corps as a nurse. In the climactic fourth act of the play, the family confronts the mandate to leave the island. Meanwhile, the nurse is missing and presumed dead.

Tang Zhongxiang [father]: Dachen is our land; we have been here for generations. When we die it will be in Dachen, its every blade of grass and every Commie bandit!

Mrs. Tang-Peng [mother]: It won't do. Our bar, our shop, this house-we should give it all up? I won't promise [to go]; I've already registered, I'm staying here to look after this property.

Tang Zhongxiang: Dachen has the property our ancestors left us; it has our ancestors' tombs. We can't abandon our ancestors' tombs and not return here! Why should we leave this place to the Commie bandits to muck up? (tears stream down his face)

Tang Bingguan [eldest]: Dad!

Mrs. Tang-Peng: (cries loudly)

Tang Bingrui [second son]: Mom!

Mrs. Tang-Peng: Your big sister's corpse hasn't been found; if we abandon her and go, it would be a shame to her!

Tang Bingjin [youngest daughter]: Dad, Mom, don't be sad! We may leave, but we'll fight our way back. Who wants to leave their home [jiaxiang 家鄉]? [Leave] the old place? I believe the government is genuinely troubled, and President Chiang is certainly even sadder than us! The

\footnotetext{
${ }^{50}$ Li-wen (Joy) Wang, "Beyond Political Propaganda: Performing Anticommunist Nostalgia in 1950s' Taiwan," Theatre History Studies 33 (2014), 193-208, 309. She cites (205) the estimate of the playwright Li Mangui 李曼瑰 that under this system of incentives and subsidies, more than one thousand plays were produced during the first two decades of ROC control of Taiwan (Li Mangui, foreword to Collections of Chinese Drama [Taipei: Center of Chinese Theater and Arts, 1970], 1:2).
} 
government has found a way to receive us in Taiwan, President Chiang hasn't forgotten us-we must go with him! ${ }^{51}$

Suffice it to say that the family does leave, and the missing daughter reunites with them in time to guide them through the evacuation.

This image of a caring leadership followed precisely from a speech Chiang Kai-shek had given on February 7, 1955, in which he attempted to wrest moral victory from the jaws of military defeat. "Strategically," he said, "I have very little regret about our military evacuating Dachen."

What our government is immensely concerned about is that the more than 17,000 civilians of Dachen—old and young, men and women—all these compatriots (tongbao 同胞) have pledged that they volunteer to follow the military in evacuating to Taiwan. What's more, they want to take this opportunity to unite civilian and military to struggle together in opposing Communism. ${ }^{52}$

Such a "voluntary pledge" had in fact been elicited through a process of registration and certification lasting precisely one week, and conducted under a state of emergency.

Yet the scene in "Farewell, Dachen!" marks a decided transition from the days in which refugee settlement planners ignored the problem of graves-and maybe even untended corpses - and created punishments to keep people in new homes in places untainted by the enemy's touch. To be sure, the coercion was much the same, in fact more severe, in 1955 than in $1938 .{ }^{53}$ But no longer was government meant to be unsentimental. In fact it was more sentimental, more feeling and emotional, than the people-in addition to of course being wiser. Such was the depth of its and the President's feeling that they would find a place for the displaced to land safely, until such time as they could "fight their way back." This line reflected an argument that the KMT spread widely: one iconic photo from the time of the evacuation shows a slogan painted on a wall as the displaced carried their belongings off Dachen: "Now, we go weeping; soon, we'll follow President Chiang back smiling!" 54 But this fourth-act exchange also laid a claim that not only was this the kind of party-state that felt, deeply, on the behalf of the people, but it was one that acknowledged their attachment to family and ancestors. "Farewell, Dachen!" paid heed to the shame of abandoning the dead without proper burial, and to the ills of leaving tombs untended. By acknowledging them, and invoking a government that cared but also knew that sacrifices were sometimes necessary, it attempted to resolve that shame and ill fortune.

Yet the most significant detail about this play is that it was not meant for an audience of Dachen refugees. They had, after all, already been safely deposited on Taiwan. Rather,

\footnotetext{
${ }^{51}$ Gao Qian 高前, Zai hui ba! Dachen! 在會吧! 大陳 (Taipei: 1955), 58-59.

${ }^{52}$ Quoted in Xin xing, 3.

${ }^{53}$ Dominic Meng-hsuan Yang makes a convincing case that the Dachen islanders were placed under a state of increasing state of terror during the period of intense militarization of the area after 1950. "From the Ashes of History: War, State Narrative, and the Displacement of Dachen Islanders in Coastal Zhejiang, 1950-1955," conference paper for "The Turmoil of History: Memories, Narratives, Representation, and Mid-Twentieth Century China," Institute of Taiwan History, Academia Sinica and The School of History, Philosophy, and Religion, Oregon State University, May 28-29, 2015.

${ }^{54}$ The photo can be seen in Dachen yibao lai Tai Wenling tongxianghui chengli shisi zhou nian jinian tekan 大陳義胞來台溫嶺同鄉會成立十四週年紀念特刊 (Yongho: Dachen yibao lai Tai Wenling tongxianghui, 1969).
} 
the play was performed in front of armed services audiences. These might have included people who had "caught a glimpse of home" while deployed on Dachen, in the words of a part waggish, part heartbreaking 1954 photo caption. ${ }^{55}$ More broadly, these were people whose thoughts about property, people, bodies, and spirits left behind had to be corralled in order to make for a proper fighting force. Naturally, controlling and guiding such emotions was all the more important in the wake of a shocking defeat, one that tied the Nationalists' future more firmly to the island. Indeed, 1955 marked a turning point in the Nationalists' military posture towards the mainland, with repercussions for social integration on Taiwan. It would be the last year in which military rank and file were forbidden from marrying, i.e. kept in a state of unsettled readiness for return.

The Nationalist government worked hard to make the Dachen "loyal comrades" into a positive political lesson for the rest of Taiwan and for the world. Some of the Dachen displaced obliged, adhering to Chiang and the party, especially in onward migration to the US in the 1970s. But overall the Dachen refugees themselves presented rather than reduced problems for the social integration of the ROC on Taiwan. They were socially, linguistically, and culturally out of place with both the main strata of mainlander groups as well as with the Taiwanese, Hakka, and indigenous persons they more frequently encountered as the state dispersed them for easier social and economic management. They also revealed rather than papered over the difficulties of leaving homes of the living and homes of the dead behind borders that were no longer traversable.

One final anecdote about the role of the dead among communities of the displaced Dachenese will serve to illustrate this point. A notable feature of the Dachen communities on Taiwan has been their ability to build and sustain temples in many of the "new villages." In some cases, the sociologist Chang Mau-kuei and others have found, this developed as a strategy for claiming property and state protection in circumstances of economic precarity; this was the origin of some of the "Lord Chiang [Kai-shek]" temples for which Dachenese became famous. ${ }^{56}$ In other instances the temples could be built because the timing of the rollout from Dachen allowed community leaders to pack up deity images for evacuation to Taiwan. Yet even these connections did not readily compensate for the loss of access to family tombs, nor for the Dachenese who died without issue.

One solution is visible at the Five Manifestations Temple (Wuxian gong 五顯宮) in Baimu village, Gaoshu township, in Pingtung (屏東縣高樹鄉百畧村). Originally built in 1957, its main hall includes deity images brought from Dachen, as well as newer additions. According to the temple manager, who had evacuated to Taiwan at age 21, the main ritual observance of the year is at the Ghost Festival, or Pudu 普渡yet this was also the feature of the temple in its community in Dachen. The Pingtung temple, however, features a side hall (功德堂) that houses the spirit tablets of Dachen community members, most of them lacking family to make offerings. Although such halls are not extremely unusual in Taiwan, the course of a conversation revealed a difference from the run of the mill. An older woman from the neighboring "new village" (now crumbling and half abandoned), the temple manager told us, came to the hall every single

\footnotetext{
${ }^{55}$ Shen, Yaochu 沈耀初, Wuwang Dachen 冊忘大陳 (Tainan: Yiming shuju, 1955).

${ }^{56}$ Chen and Chang, "Cong 'Dachen yibao.",
} 
day to make a collective offering to the spirits. Upon hearing this piece of information the entire assembled group of visitors-including locals of Hakka, and Taiwanese (Minnan), background, as well as the temple manager's grandson-expressed surpise. It was, everyone concluded, very different from the way people usually did things in Taiwan, to come to such a hall every single day. ${ }^{57}$

The daily offering at the Five Manifestations Temple Gongde Hall presents something of an inverse and counterpart to the ghost temples that proliferate in the ROC-onTaiwan's most heavily militarized places, especially Jinmen and the Matsu Islands. Such temples, such as those to Wang Yulan and to the Patriotic Generals studied by Chi Chang-hui and Michael Szonyi, exist in the first instance to propitiate ghosts presented by the appearance in the community of untended corpses. In the case of the offshore islands, many of these were literally washed up by the tide. Although the nature of the islands' geography meant that some temples and cults dated back as early as the Ming dynasty (this is especially the case on Matsu), others were byproducts of the intensified militarization of the twentieth century. The cults of Wang Yulan and the Patriotic Generals originated in the corpses produced by the civil and Cold wars, and their temples likewise became sites of Cold War political and social contestation, as Szonyi shows. ${ }^{58}$

The Dachen temples, and the Five Manifestations Gongde Hall in particular, were not attempts to propitiate and incorporate potentially destabilizing forces from the outside. Rather, they were created from the subject position of the potentially destabilizing outside force, and as means of managing the specific problems raised by a community's displacement. Temple-building being a basic element of migration in Chinese societies, on one level the Dachen temples simply followed a familiar pattern. But on another, they also address the particular problems raised by violent displacement. One was a scramble for economic footing out of a position simultaneously privileged by the attention of the state and hobbled by it. Another was a surfeit of untended yet familiar ghosts.

\section{CONCLUSION: THE LAND WHERE NONE OF YOUR RELATIVES ARE BURIED}

The daily care for the spirit tablets of the Five Manifestations Gongde Hall may well turn out to be a phenomenon tightly circumscribed by time. Indeed, the temple manager's grandson, who lived and ran a betel nut shop close by, did not know about the daily visitor until our interview. It does not necessarily follow, however, that the passage of time will definitively settle the displacement of the dead.

Such a point was made by Chu T'ien-hsin, albeit in an unexpected fashion. The narrator of "In Remembrance of My Buddies from the Military Compound" explains her

\footnotetext{
${ }^{57}$ Interview with Mr. A., Baishu Village, Gaoshu township, Pingtung county, Taiwan, June 16, 2016. Information about the temple is included in the "Taiwan waisheng ren" database: http://ndweb.iis.sinica.edu.tw/ TWM/Public/content/story/collectable.jsp?pk=534. See also Wu Zhongjie 吳中杰, “Duo zu qun hunju xia de yuyan yu kongjian bianqian-yi Gaoshu xiang Dongzhen, Dapu cun wei li” “多族群混居下的語言與空 間變遷一以高樹鄉東振、大埔村為例,” in National Sun Yat-sen University 國立高雄師範大學, Nan Taiwan de Kejia yuyuan yu zuqun guanxi yanjiu jihua「南臺灣的客家語言與族群關係研究計畫」 (Taipei: Kejia weiyuanhui, 2010), 137-84.

${ }^{58}$ Chi Chang-hui, "The Politics of Deification and Nationalist Ideology: A Case Study of Quemoy” (PhD diss., Boston University, 2000); Michael Szonyi, Cold War Island: Quemoy on the Front Line (Cambridge: Cambridge University Press, 2008), 181-97.
} 
stark statement about alienation and home by describing the emotional state the Qingming festival would engender in the soldiers' relatives, as witnessed by its children:

Always the day would pass by with no special ceremony. When night fell and they went home for dinner, they would find their parents acting strangely. Some would be burning paper money in their backyard, but because they did not know whether their relatives back home were alive, they could only state ambiguously that the money was burned for ancestors of $\mathrm{X}$ family. Therefore, their expressions were especially complicated - they dared not express grief, their faces would be marked by memories made all the more lucid and poignant by the passage of time.

So, a land where none of your relatives are buried cannot be called a home.

Writing this in 1992, Chu used the problems of ritual, burial and missing bodies as a means of working through some of the ethnic, political and place-making ambiguities of "mainlander" and "Taiwanese" status during the early years of democratization. But such quandaries were not simply figures of her own invention, regardless of the broader uses to which she put them. Five years after the publication of that story, Chu made an authorial intervention into her narrator's proclamation, via a discussion between another two characters in her novella "The Old Capital." Now her focus was landscape and its connection to place and home feeling through the trace of human activity and history:

I remember a novelist with a background similar to yours once wrote, "A land where none of your relatives are buried cannot be called home." You didn't have this kind of burden, only used to wearily ask of anyone, no matter what their background... whether a place that didn't intend to preserve the scars of human existence would not become an alien city. ${ }^{59}$

Much can be made of Chu's doubling back on herself and her creation in this way, whether from a technical point of view or a political one. What interests me here is Chu's willingness to reconsider the flexibility of ritual as well as memory, and address - as she does over the length of the novella-how both can become attached to new as well as old places over time, even as one is disappointed by the changes wrought upon the old.

Yet we might extrapolate her insistence on the retaining of the "scars of human existence"-which in the novella are the physical characteristics of a city like Taipei, the plants, buildings and bridges brought by successive colonizers and migrants - to serve as a reminder that "home" can be configured in multiple ways for the displaced, often simultaneously as well as successively, ritually as well as physically. Too often state schemes to mobilize or strategize the presence of refugees sought to restrict their sense of place to a single location and a single iteration. They did so by attempting to redirect attention from one old home to a new one, or from the family or locality to the state. They offered up rewards and punishments to stave off home cravings or to redirect populations in ways that best served political and military interests or assuaged fears of social disruption. Thus strategic secondary displacement became the mechanism to keep human assets

\footnotetext{
${ }^{59}$ Chu T'ien-hsin, The Old Capital: A Novel of Taipei, trans. by Howard Goldblatt (New York: Columbia University Press, 2007). A fine analysis of the role of memory in Chu T'ien-hsin and other "mainlander" literary works is Peng Hsiao-Yen, "Representation Crisis: History, Fiction and Post Martial-Law Writers from the 'Soldiers' Villages'," positions 17 (2009), 375-410.
} 
in check. In its very nature, secondary displacement eschewed addressing the concerns that would have contributed to a sense of security and emplacement for the people in question. Among these was the broadest sense of shanhou, the settling of the dead.

In 1946 Wang Daojin, was overseeing the chaotic postwar refugee scene in Wuhan, the major transit point for people attempting to get back east, north, and south from what had been the Nationalist wartime base of power. He noted that something was missing in the schemes for relief of the displaced:

The refugees come. We give them something to eat, we give them a place to stay, and we send them on their way. Is this the whole of our work? It cannot be that simple. We must give them all of the knowledge necessary for every eventuality, and we have to make them understand the goal of our work.

Moreover, each refugee has his own suffering, has his own hopes. Many people's suffering needs alleviation, many people's hopes need fulfilling.

Wang recognized his impotence at dealing with this level of the problem. Nonetheless, he took the time to include the matter in an otherwise nuts-and-bolts manual about how to house and move large numbers of refugees that, from his logistical point of view, were often difficult to manage. That is, Wang Daojin recognized that displacement consisted of linked physical and psychological states. ${ }^{60}$

By examining the connection between the displacement of the living and of the dead, I am attempting one angle at opening up the connection between those states. I also hope this research will elucidate the connection between the movements of individuals, families and other small-scale groups and the larger government efforts to plan patterns for arranging and deploying refugees that developed during the "long war." In particular, the displaced dead highlight the disconnect between mass political mobilization and nationalist claims made during the course of twentieth-century total warfare, and the extreme cases of drifting, exile, and familial and community separation it caused.

Finally, these examples are a way of demonstrating that the bodies of civilian as well as military dead constitute the texts of modern mass violence. These texts arrange themselves, and deserve reading, in ways that reach beyond the numerical obsessions that have driven our historical frameworks of this period thus far. How did people die during the period that I am calling the "long war" in China and Taiwan? It is startling to think that, with all the research that has been devoted to this subject-the Second Sino-Japanese War above all-in China, Taiwan, and overseas in recent decades, our sense of this can still remain so vague. Let me be clear: when I say "how" I do not mean the mechanisms by which people came to their deaths. This, indeed, we know all too well—not only the direct fighting, bombing, and overt atrocities, but the disease, floods, and famines. Rather, I am thinking of the process and processing of death.

The literature and study of war has focused our attention on numbers and numerical wars (300,000 as a counterpart to six million), or to a focus on the exemplary or singular death (commemoration and collective memory). In a time of war upon war, death upon

\footnotetext{
${ }^{60}$ Wang Daojin 王道謹, Nanmin de zhaodai yu shusong 難民的招待與輸送 (Wuhan: Xing zong E shu Wuhan banshi chu, 1946), 6 .
} 
death, perhaps it is not the most horrible, the most numerous, or the most famous that we should be looking for in order to understand how people were affected. Instead, perhaps we can ask: what kinds of death could people grasp? What kinds of bodies could they, quite literally, handle? Which remained out of their reach? To begin to understand history on this level would be to begin to comprehend the scope of displacement in twentieth-century China and Taiwan. 